JPDN ISSN 2579-6461 (Online) ISSN 2460-6324 (Print)

Jurnal Pendidikan Dasar Nusantara

Volume 6| Nomor $1 \mid$ Juli $2020 \mid$

DOI: https://doi.org/10.29407/jpdn.v6i1.14423

\title{
PENANAMAN KARAKTER PEDULI LINGKUNGAN PADA SISWA DI SD NEGERI SUKAMULYA I MELALUI PROGRAM KURASSAKI
}

\author{
Annisa Siti Rufaidah ${ }^{1}$, Suparno $^{2}$, Ujang Jamaludin ${ }^{3}$ \\ Annisasitirufaidah@gmail.com ${ }^{1,}$ Suparno101@ @mail.com ${ }^{2}$, \\ Ujangjamaludin@untirta.ac.id ${ }^{3}$ \\ PGSD, FKIP, Universitas Sultan Ageng Tirtayasa \\ No Handphone: +6281383438904
}

\begin{abstract}
Abstrak: Penelitian ini bertujuan untuk mengetahui penanaman karakter peduli lingkungan pada siswa di SDN Sukamulya I melalui program Kurassaki. Penelitian ini menggunakan metode penelitian kualitatif deskriptif, narasumber dalam penelitian ini adalah kepala sekolah, guru, dan siswa. Teknik pengumpulan data yang digunakan yaitu wawancara, observasi, dan dokumentasi, yang kemudian dianalisis dengan menggunakan model Miles dan Huberman. Hasil dari penelitian ini menunjukkan bahwa: 1) Penanaman karakter peduli lingkungan pada siswa di SDN Sukamulya I melalui program Kurassaki dilaksanakan melalui tiga tahapan: tahap perencanaan, tahap pelaksanaan, dan tahap evaluasi 2) Faktor pendukung dan penghambat dalam pelaksanaan program Kurassaki, faktor pendukung dari guru yaitu adanya pelatihan dari pembina program Kurassaki yang diikuti oleh guru untuk mengoptimalkan pelaksanaan program, dari siswa adalah karakteristik anak sekolah dasar yang masih bersifat imitatif memudahkan siswa untuk diarahkan dan berpartisipasi dalam pelaksanaan program, dari sarana dan prasarana yaitu tersedianya sarana dan prasarana yang menunjang. Hambatan dari siswa yaitu lupa membawa tempat makanan dan minuman, serta kurangnya tanggung jawab dalam pemeliharaan alat kebersihan, dari sarana dan prasarana adalah terdapat alat kebersihan yang rusak dan hilang.
\end{abstract}

Kata kunci : Pendidikan karakter di SD, Karakter peduli lingkungan, program Kurassaki.

\section{INCULCATION OF ENVIRONMENTAL CARE CHARACTERS IN STUDENTS OF SD NEGERI SUKAMULYA I THROUGH KURASSAKI PROGRAM}

\begin{abstract}
This study aims to determine the inculcation of environmental care character among students at SDN Sukamulya I through the Kurassaki program. This study uses descriptive qualitative research methods, the resource persons in this study are the principal, teachers, and students. Data collection techniques used were interviews, observation, and documentation, which were then analyzed using the Miles and Huberman models. The results of this study indicate that: 1) Planting environmental care characters in students at SDN Sukamulya I through the Kurassaki program is carried out through three stages: the planning stage, the implementation phase, and the evaluation stage 2) Supporting and inhibiting factors in the implementation of the Kurassaki program, supporting factors of teacher namely the existence of training from
\end{abstract}


Annisa, Suparno, Ujang. Penanaman Karakter Peduli Lingkugan

the Kurassaki program supervisor who was followed by the teacher to optimize the implementation of the program, from students the characteristics of elementary school children who are still imitative make it easy for students to be directed and participate in the implementation of the program, from facilities and infrastructure that is the availability of supporting facilities and infrastructure. Barriers from students are forgetting to bring food and drink containers, as well as lack of responsibility in maintaining cleaning equipment, from facilities and infrastructure, there are damaged and missing cleaning equipment.

Keywords: Character education in elementary school, Character care for the environment, Kurassaki program.

\section{PENDAHULUAN}

Pendidikan di Indonesia saat ini sedang gencar-gencarnya menanamkan karakter pada diri peserta didik dengan tujuan agar terlahirnya lulusan yang berkarakter. Menurut Purwanto (2016:10) karakter dianggap sama dengan kepribadian. Kepribadian dianggap sebagai ciri khas atau karakteristik, keistimewaan sifat seseorang ini dapat terbentuk dan dipengaruhi oleh lingkungan, misalnya lingkungan keluarga sejak masa kecil, dan juga bawaan seseorang sejak lahir. Karakter merupakan watak atau perilaku yang menjadi ciri khas seseorang dalam bertindak, karakter tidak terbentuk dalam waktu yang singkat, melainkan berkembang melalui tahapan-tahapan serta pembiasaan sejak dini, hal tersebut dapat dilakukan salah satunya melalui proses pendidikan.

Karakter yang perlu ditanamkan pada peserta didik melalui proses pendidikan salah satunya adalah karakter peduli lingkungan. Menurut Kemendiknas (2010) karakter peduli lingkungan adalah sikap dan tindakan yang selalu berupaya mencegah kerusakan lingkungan alam di sekitarnya dan mengembangkan upaya-upaya untuk memperbaiki kerusakan alam yang sudah terjadi. Lingkungan merupakan tempat dimana manusia tinggal dan melakukan berbagai aktivitas. Setiap individu memiliki kewajiban dan tanggung jawab untuk menjaga dan merawat lingkungan sekitar, bukan hanya orang dengan profesi tertentu seperti tukang kebun, petugas kebersihan dan profesi lainnya yang bertanggungjawab dalam merawat lingkungan. Namun, pada kenyataannya kepekaan dan kepedulian masyarakat Indonesia terhadap kebersihan lingkungan sekitar masih sangat rendah. Dari data riset Kementerian Kesehatan diketahui hanya $20 \%$ dari total masyarakat Indonesia yang peduli terhadap kebersihan dan kesehatan. Ini berarti, dari 262 juta jiwa di Indonesia, hanya sekitar 52 juta orang yang memiliki kepedulian 
Annisa, Suparno, Ujang. Penanaman Karakter Peduli Lingkugan

terhadap kebersihan lingkungan sekitar dan dampaknya terhadap kesehatan (Sumber: CNN Indonesia 23 April 2018).

Permasalahan di atas membuktikan bahwa pentingnya penanaman karakter peduli lingkungan sejak dini, karakter peduli lingkungan dapat ditanamkan melalui lingkungan keluarga dan lingkungan sekolah. Terdapat beberapa permasalahan di lingkungan sekolah yang berkaitan dengan kebersihan lingkungan. Balai Pengembangan Media Televisi Pendidikan dan Kebudayaan menginformasikan bahwa beberapa permasalahan yang muncul dalam menjaga kebersihan lingkungan sekolah bermacammacam, mulai dari kurangnya sarana dan prasarana kebersihan sampai kurangnya kesadaran warga sekolah dalam menjaga kebersihan lingkungan sekolah. Masalahmasalah yang sering muncul diantaranya adalah membuang sampah sembarangan dan kurangnya penanganan dan pengelolaan sampah di sekolah (Sumber: BPMTV Kemdikbud 30 Agustus 2017). Banyaknya permasalahan tersebut membuktikan bahwa masih kurangnya kepekaan dan kepedulian warga sekolah terhadap kebersihan lingkungan sekitarnya, hal tersebut mencerminkan bahwa penanaman karakter peduli lingkungan di sekolah belum terlaksana dengan baik. Kondisi tersebut mendorong diperlukannya memberikan pemahaman kepada generasi muda di Indonesia tentang pentingnya kepedulian terhadap lingkungan.

Ninsih, Winarni, \& Karjiyati (2018) dalam penelitiannya menjelaskan bahwa menanamkan karakter peduli lingkungan di sekolah dapat dilakukan dengan cara melatih dan mebiasakan siswa untuk menjaga kebersihan lingkungan dan mencegah terjadinya pecencemaran lingkungan melalui program di sekolah yang berkaitan dengan penanaman karakter peduli lingkungan. Badan Perencanaan Pembangunan Daerah (Bappeda) Kabupaten Tangerang melakukan upaya untuk mengatasi persoalan sampah melalui program Kurangi Sampah Sekolah Kita (Kurassaki). Prinsip dari program ini adalah mengurangi sampah di sekolah dengan mengubah pola hidup siswa. Pada awalnya siswa yang setiap hari menghsilkan sampah dari kemasan jajanan, kini diwajibkan membawa bekal makan dan minum dari rumah, atau menggunakan tempat makan dan minum tersebut untuk membeli jajanan, hal ini berguna untuk mengurangi volume sampah dari kemasan jajanan di sekolah (Sumber: Bappeda Kabupaten Tangerang 17 Oktober 2016). 


\section{Annisa, Suparno, Ujang. Penanaman Karakter Peduli Lingkugan}

Berdasarkan hasil wawancara pra penelitian yang telah peneliti lakukan di SDN Sukamulya I, sekolah tersebut merupakan salah satu sekolah yang mendukung program pemerintah dengan melaksanakan program Kurassaki. Program ini dijadikan sebagai wadah dalam menanamkan karakter peduli lingkungan pada siswa di SDN Sukamulya I. SD Negeri Sukamulya I merupakan sekolah pertama yang menanamkan karakter peduli lingkungan pada siswa melalui program Kurassaki di Kecamatan Cikupa, dan mendapatkan predikat pertama sekolah bersih tingkat kecamatan. Program Kurassaki dirasa dapat menjadi solusi bagi pihak sekolah untuk membentuk karakter peduli lingkungan pada siswa. Oleh sebab itu, peneliti tertarik untuk mengetahui labih jauh tentang Penanaman Karakter Peduli Lingkungan Pada Siswa Di SD Negeri Sukamulya I melalui Program Kurassaki, sehingga dirumuskan tujuan dari penelitian ini untuk mendeskripsikan, (1) pelaksanaan program Kurassaki dalam menanamkan karakter peduli lingkungan pada siswa, (2) faktor pendukung dan penghambat pelaksanaan program Kurassaki dalam menanamkan karakter peduli lingkungan pada siswa.

\section{METODE}

Penelitian ini menggunakan metode penelitian kualitatif yang hasilnya berupa data deskriptif. Menurut Strauss dan Corbin dalam Cresswell, J, 1998 (dalam Rahmat, 2009) kualitatif merupakan jenis penelitian yang hasil temuannya tidak bisa diperoleh dengan cara pengukuran (kuantifikasi) ataupun menggunakan prosedur statistik. Secara umum penelitian ini dapat digunakan untuk penelitian tentang karakter, kehidupan masyarakat, kegiatan sosial, sejarah, dan lain sebagainya. Penelitian kualitatif lebih mementingkan proses dibandingkan dengan hasil, dan instrumen dalam penelitian ini adalah peneliti itu sendiri (Mulyadi, 2011). Penelitian ini dilakukan dengan mengambil tempat di SDN Sukamulya I tahun ajaran 2019/2020. Pemilihan lokasi ini didasarkan atas beberapa pertimbangan, dan dimulai sejak bulan Januari sampai Maret 2020. Sumber data diperoleh dari Kepala sekolah, guru, dan siswa SDN Sukamulya I. Teknik pengumpulan data yang digunakan yaitu wawancara semiterstruktur yang merupakan jenis wawancara in-depth interview, observasi tak berstruktur, dan dokumentasi, yang kemudian dianalisis dengan menggunakan model Miles dan Huberman. Pada penelitian ini uji keabsahan data menggunakan cara triangulasi sumber dan triangulasi tenik. Triangulasi sumber data untuk menguji kredibilitas data dilakukan dengan cara melakukan wawancara kepada kepala sekolah SD Negeri Sukamulya I, guru, dan siswa. 
Annisa, Suparno, Ujang. Penanaman Karakter Peduli Lingkugan

Triangulasi teknik untuk menguji kredibilitas data dilakukan dengan cara mengecek data yang diperoleh kepada sumber data yang sama dengan teknik yang berbeda. Triangulasi teknik penelitian ini menggunakan teknik wawancara, observasi, dan dokumentasi pada proses penanaman karakter peduli lingkungan melalui program Kurassaki (Kurangi Sampah Sekolah Kita) di SD Negeri Sukamulya I.

\section{HASIL}

Pada bagian ini dipaparkan hasil penelitian yang meliputi hasil observasi, dan hasil wawancara.

\section{Tabel 4.1 Hasil Observasi}

\begin{tabular}{|c|c|c|}
\hline $\begin{array}{c}\text { Aspek yang } \\
\text { diamati }\end{array}$ & Deskripsi aspek yang diamati & Kesimpulan \\
\hline $\begin{array}{l}\text { Perencanaan } \\
\text { program } \\
\text { Kurassaki }\end{array}$ & $\begin{array}{l}\text { Kamis, 6 Februari } 2020 \\
\text { Terdapat struktur penanggung jawab pelaksanaan program } \\
\text { Kurassaki yang tertera dalam proposal program. Bu Novi } \\
\text { merupakan ketua penanggung jawab pelaksanaan program } \\
\text { Kurassaki sekaligus sebagai guru UKS. Struktur } \\
\text { penanggung jawab pelaksanaan program Kurassaki telah } \\
\text { dibuat sejak awal dilaksanakannya program ini, yaitu pada } \\
\text { tahun } 2017 \text {. } \\
\text { Jumat, } 7 \text { Februari } 2020 \\
\text { Tersedia tempat cuci tangan di depan setiap kelas, kecuali } \\
\text { di depan gedung kelas baru, gedung baru ditempati oleh } \\
\text { siswa kelas I dan II. } \\
\text { Tidak tersedia tempat sampah di dalam kelas I dan II. } \\
\text { Senin, } 10 \text { Februari } 2020 \\
\text { Tersedia sanitasi untuk siswa laki-laki dan sanitasi untuk } \\
\text { siswa perempuan. Sanitasi siswa laki-laki dilengkapi } \\
\text { dengan satu wastafel cuci tangan beserta satu cermin, dua } \\
\text { urinoir dan dua kamar mandi. Sedangkan sanitasi untuk } \\
\text { siswa perempuan terdiri dari tiga kamar mandi, satu } \\
\text { wastafel cuci tangan beserta satu cermin. Terdapat juga } \\
\text { dua sanitasi yang disediakan untuk guru beserta sabun. } \\
\text { Sanitasi yang disediakanpun bersih dan tidak berbau. } \\
\text { Sabtu, } 15 \text { Februari } 2020 \\
\text { Terdapat slogan-slogan tentang kebersihan yang dipajang } \\
\text { di lingkungan sekolah, terdapat slogan kawasan bebas } \\
\text { rokok, tersedia alat kebersihan, sekolah tidak } \\
\text { menyediakan tempat sampah di lingkungan sekolah. } \\
\text { Senin, } 17 \text { Februari } 2020 \\
\text { Tata tertib Kurassaki dipajang di dinding gedung sekolah, } \\
\text { peneliti diperlihatkan proposal pelaksanaan program }\end{array}$ & $\begin{array}{l}\text { Pihak sekolah } \\
\text { membuat } \\
\text { perencanaan } \\
\text { program } \\
\text { Kurassaki } \\
\text { yang meliputi } \\
\text { penyusunan } \\
\text { program } \\
\text { kegiatan, } \\
\text { penyediaan } \\
\text { sarana dan } \\
\text { prasarana, } \\
\text { serta } \\
\text { membentuk } \\
\text { struktur } \\
\text { penanggung } \\
\text { jawab. }\end{array}$ \\
\hline
\end{tabular}


Annisa, Suparno, Ujang. Penanaman Karakter Peduli Lingkugan

\begin{tabular}{|c|c|c|}
\hline & $\begin{array}{l}\text { Kurassaki oleh bu Novi, beliau juga memberikan soft file } \\
\text { proposal tersebut kepada peneliti. } \\
\text { Sabtu, } 22 \text { Februari } 2020 \\
\text { Pihak sekolah telah merencanakan pelaksanaan program } \\
\text { Kurassaki sejak awal, dari membuat struktur penanggung } \\
\text { jawab pelakasnaan program, menyiapkan sarana dan } \\
\text { prasarana yang menunjang pelaksanaan program } \\
\text { Kurassaki, serta menentukan aturan-aturan didalamnya. }\end{array}$ & \\
\hline $\begin{array}{l}\text { Pelaksanaan } \\
\text { kegiatan } \\
\text { program } \\
\text { Kurassaki }\end{array}$ & $\begin{array}{l}\text { Kamis, 6 Februari } 2020 \\
\text { Siswa kelas V dan VI terlihat sedang melakukan piket } \\
\text { kelas sebelum KBM dimulai, sampah yang terkumpul } \\
\text { tidak banyak hanya debu-debu saja, mereka menggunakan } \\
\text { plastik sebagai pengganti tempat sampah. Siswa mencuci } \\
\text { tangan setelah piket. Siswa membawa tempat makan dan } \\
\text { tempat minum dari rumah, mereka menggunakannya } \\
\text { untuk jajan dijadikan sebagai pengganti bungkus kemasan } \\
\text { atau styrofoam yang biasa digunakan. } \\
\text { Jumat, } 7 \text { Februari } 2020 \\
\text { Siswa kelas I dan II piketnya masih didampingi oleh guru, } \\
\text { terlihat siswa membawa tempat makan dan minum dari } \\
\text { rumah, mencuci tangan setelah selesai melakukan } \\
\text { kegiatan dan sebelum serta setelah selesai makan, siswa } \\
\text { mengikuti kegiatan kultum dengan membaca Asmaul } \\
\text { husna, tadarus membaca Al-Quran, serta mendengarkan } \\
\text { ceramah dari guru agama dengan tentang kebersihan } \\
\text { sebagian dari iman. Selain itu, peneliti juga melihat siswa } \\
\text { kelas V yang sedang bermain game estafet tongkat. } \\
\text { Senin, } 10 \text { Februari } 2020 \\
\text { Guru kelas I mengawasi siswanya saat piket, terlihat siswa } \\
\text { mencuci tangannya setelah selesai piket, terdapat siswa } \\
\text { yang membawa dan juga tidak membawa tempat makan } \\
\text { atau minum dari rumah, siswa yang tidak membawa } \\
\text { tempat makan atau minum dari rumah tidak boleh } \\
\text { membawa jajanannya ke lingkungan sekolah, mereka } \\
\text { menghabiskannya di depan gerbang sekolah atau di dekat } \\
\text { tempat pedagang jajanan tersebut, lingkungan sekolah dan } \\
\text { kelas terlihat bersih tidak ada sampah. Guru melakukan } \\
\text { pemeriksaan kuku sebelum KBM dimulai. } \\
\text { Sabtu, } 15 \text { Februari } 2020 \\
\text { Siswa terlihat melakukan piket, setelah bel berbunyi siswa } \\
\text { dan guru melaksanakan kegiatan apel, kemudian } \\
\text { melakukan kegiatan senam bersama, kerja bakti } \\
\text { membersihkan lingkungan sekolah dan lingkungan sekitar } \\
\text { sekolah, setelah selesai melakukan kerja bakti, siswa } \\
\text { menaruh kembali alat kebersihan yang digunakan dan } \\
\text { mencuci tangannya di wastafel atau sanitasi sekolah, } \\
\text { setelah itu siswa memakan bersama-sama bekal yang }\end{array}$ & $\begin{array}{l}\text { Pelaksanaan } \\
\text { program } \\
\text { Kurassaki } \\
\text { terdiri dari } \\
\text { kegiatan rutin } \\
\text { harian dan } \\
\text { mingguan. } \\
\text { Kegiatan rutin } \\
\text { yang } \\
\text { dilakukan } \\
\text { setiap harinya } \\
\text { yaitu piket, } \\
\text { membawa } \\
\text { kantung } \\
\text { plastik, } \\
\text { mencuci } \\
\text { tangan, serta } \\
\text { membawa } \\
\text { tempat makan } \\
\text { dan minum } \\
\text { pribadi. } \\
\text { Kegiatan } \\
\text { mingguannya } \\
\text { meliputi } \\
\text { pemeriksaan } \\
\text { kuku dan } \\
\text { SABSIH } \\
\text { (Sabtu } \\
\text { bersih), } \\
\text { kegiatannya } \\
\text { meliputi kerja } \\
\text { bakti } \\
\text { membersihka } \\
\text { n lingkungan } \\
\text { sekolah dan } \\
\text { sekitarnya, } \\
\text { senam, dan } \\
\text { makan } \\
\text { bersama, serta }\end{array}$ \\
\hline
\end{tabular}


Annisa, Suparno, Ujang. Penanaman Karakter Peduli Lingkugan

\begin{tabular}{|c|c|c|}
\hline & $\begin{array}{l}\text { mereka bawa di lapangan sekolah. } \\
\text { Senin, 17 Februari } 2020 \\
\text { Pagi hari peneliti melihat keadaan kantor yang bersih dan } \\
\text { wangi, kemudian keluar dan melihat siswa yang sedang } \\
\text { piket membersihkan kelas, peneliti juga melihat siswa } \\
\text { mencuci tangannya di wastafel cuci tangan, selain itu } \\
\text { peneliti juga melihat guru melakukan pemeriksaan kuku } \\
\text { kepada siswanya seblum KBM dimulai. Siswa terlihat } \\
\text { membawa tempat makan dan minum dari rumah, peneliti } \\
\text { juga melihat siswa yang sedang menghabiskan } \\
\text { makanannya di depan gerbang sekolah karena tidak } \\
\text { membawa tempat makan atau tempat minum dari rumah. } \\
\text { Sabtu, } 22 \text { Februari } 2020 \\
\text { Pukul 07.00 siswa dan guru sedang bersiap untuk } \\
\text { melakukan senam bersama, guru terlihat memimpin } \\
\text { senam di depan. Setelah kegiatan senam selesai peneliti } \\
\text { melihat siswa istirahat sebentar sebelum melakukan } \\
\text { kegiatan kerja bakti, kemudian siswa berkumpul kembali } \\
\text { di lapangan sekolah dengan sudah membawa alat } \\
\text { kebersihan, guru membagi siswa menjadi beberapa } \\
\text { kelompok untuk membersihkan kelas, lingkungan dalam } \\
\text { sekolah, dan lingkungan sekitar sekolah. Setelah selesai } \\
\text { kerja bakti, siswa terlihat membersihkan tangannya } \\
\text { dengan mencuci tangan di wastafel atau sanitasi sekolah. } \\
\text { Kemudian siswa terlihat mengambil bekal makanan atau } \\
\text { membeli jajanan, dan memakannya bersama-sama di } \\
\text { lapangan sekolah. Setelah selesai makan, siswa terlihat } \\
\text { dibagi menjadi beberapa kelompok untuk melakukan } \\
\text { game, permainan yang dilakukan adalah membuat pot } \\
\text { untuk tanaman dari botol bekas, hal ini dilakukan agar } \\
\text { siswa dapat memanfaatkan barang bekas sebagai bahan } \\
\text { untuk membuat suatu kerajinan tangan. }\end{array}$ & $\begin{array}{l}\text { melakukan } \\
\text { kegiatan fun } \\
\text { game. }\end{array}$ \\
\hline $\begin{array}{l}\text { Evaluasi } \\
\text { pelaksanaan } \\
\text { program } \\
\text { Kurassaki }\end{array}$ & $\begin{array}{l}\text { Kamis, 6 Februari } 2020 \\
\text { Peneliti menanyakan buku pengecekan pelaksanaan } \\
\text { program Kurassaki kepada bu Novi, lalu beliau } \\
\text { memperlihatkan buku tersebut ke peneliti. Peneliti } \\
\text { diberikan file softcopy-annya untuk dijadikan sebagai } \\
\text { lampiran. } \\
\text { Jumat, } 7 \text { Februari } 2020 \\
\text { Guru terlihat melakukan penilaian kesetiap kelas, } \\
\text { penilaian ini dilakukan untuk melihat kebersihan setiap } \\
\text { kelas. } \\
\text { Senin, 10 Februari } 2020 \\
\text { Pembina upacara memberikan himbauan kepada seluruh } \\
\text { warga sekolah untuk menjaga kebersihan dan memelihara } \\
\text { fasilitas yang telah disediakan oleh sekolah, memeriksa } \\
\text { kerapihan dan kelengkapan pakaian siswa setelah upacara }\end{array}$ & $\begin{array}{l}\text { Tidak ada } \\
\text { penilaian } \\
\text { khusus dalam } \\
\text { evaluasi, } \\
\text { sekolah hanya } \\
\text { melakukan } \\
\text { rapat secara } \\
\text { berkala setiap } \\
\text { minggunya } \\
\text { untuk } \\
\text { membahas } \\
\text { segala } \\
\text { kegiatan di } \\
\text { sekolah } \\
\text { termasuk }\end{array}$ \\
\hline
\end{tabular}


Annisa, Suparno, Ujang. Penanaman Karakter Peduli Lingkugan

\begin{tabular}{|l|l|l|}
\hline \hline Selesai. & pelaksanaan \\
Sabtu, 15 Februari 2020 & program \\
Setelah siswa pulang sekitar jam 11.00, guru melakukan & Kurassaki, \\
rapat yang rutin dilakukan setiap minggunya. & melakukan \\
Senin, 17 Februari 2020 & pengecekan \\
pelaksanaan \\
Setelah pembina upacara selesai memberikan wejangan \\
kepada siswa, pak Nafis memberikan pengumuman tiga \\
kelas yang menjadi kelas bersih di bulan Februari. & program \\
Surassaki dan \\
Sabtu, 22 Februari 2020 & mengumumka \\
Pihak sekolah mengadakan permainan fun game) & n tiga kelas \\
membuat pot tanaman dari botol bekas yang dihias & terbersih \\
& sekreatif mungkin oleh siswa. Guru melakukan rapat yang & setiap \\
rutin dilakukan setiap minggunya. & bulannya. \\
\hline
\end{tabular}

\section{Tabel. 4.2 Hasil Wawancara}

\begin{tabular}{|c|c|}
\hline & \\
\hline $\begin{array}{l}\text { 1. Apa } \\
\text { deng } \\
\text { Kura }\end{array}$ & $\begin{array}{l}\text { Kurassaki merupakan program dari dinas kabupaten Tangerang } \\
\text { untuk mengurangi jumlah volume sampah di Tangerang, dalam } \\
\text { pelaksanaannya siswa diminta untuk membwa tempat makan } \\
\text { dan minum dari rumah agar sampah yang dihasilkan siswa dari } \\
\text { kemasan jajanan dapat berkurang. }\end{array}$ \\
\hline $\begin{array}{l}\text { 2. Apa saja persiapan } \\
\text { yang diperlukan } \\
\text { untuk } \\
\text { melaksanakan } \\
\text { program Kurassaki? }\end{array}$ & $\begin{array}{l}\text { Persiapan yang dilakukan oleh pihak sekolah sebelum } \\
\text { melaksanakan program Kurassaki, yaitu dengan melakukan } \\
\text { rapat terlebih dahulu terkait bagaimana pelaksanaannya, } \\
\text { menentukan siapa penanggungjawabnya, apa saja aturan di } \\
\text { dalamnya, sarana dan prasarana apa saja yang dibutuhkan, } \\
\text { menentukan sanksi yang dapat mengedukasi bagi pelanggar, } \\
\text { dan melakukan penyuluhan kepada siswa terkait pelaksanaan } \\
\text { dan aturan di dalamnya. }\end{array}$ \\
\hline $\begin{array}{l}\text { Sara } \\
\text { pras } \\
\text { dise } \\
\text { untu } \\
\text { pela } \\
\text { prog }\end{array}$ & $\begin{array}{l}\text { disediakan oleh } \\
\text {, wastafel cuci } \\
\text { guru dan siswa } \\
\text { k menyediakan }\end{array}$ \\
\hline $\begin{array}{l}\text { nikasi } \\
\text { olah } \\
\text { tua } \\
\text { agang } \\
\text { h } \\
\text { anaan }\end{array}$ & $\begin{array}{l}\text { Pihak sekolah mengkomunikasikan terkait pelaksanaan } \\
\text { program Kurassaki kepada orang tua siswa melalui grup } \\
\text { WhatsApp untuk mempermudah dalam pelaksanaannya, } \\
\text { sehingga siswa mendapatkan perhatian di sekolah dan juga di } \\
\text { rumah, selain itu pihak sekolah juga mengkomunikasikannya } \\
\text { dengan pedagang. }\end{array}$ \\
\hline $\begin{array}{l}\text { 5. Apc } \\
\text { yan } \\
\text { seb } \\
\text { har }\end{array}$ & $\begin{array}{l}\text { kukan setiap hari oleh siswa, yaitu } \\
\text { dan minum dari rumah, piket kelas, } \\
\text { etelah melakukan kegiatan terutama } \\
\text { an. }\end{array}$ \\
\hline
\end{tabular}


Annisa, Suparno, Ujang. Penanaman Karakter Peduli Lingkugan

6. Apa saja kegiatan yang dilakukan dalam program mingguan?

7. Dalam pelaksanaan kegiatannya apakah siswa didampingi oleh bapak/ibu guru?

8. Bagaimana kegiatan evaluasi yang dilakukan dalam pelaksanaan program Kurassaki?

9. Apa yang menjadi faktor pendukung dalam pelaksanaan program Kurassaki dari sisi guru?
Kegiatan rutin yang dilakukan setiap minggunya, yaitu SABSIH (Sabtu bersih) meliputi kegiatan kerja bakti membershkan lingkungan sekolah, senam bersama, dan makan bersama.

Setiap kegiatan yang dilakukan oleh siswa selalu didampingi oleh guru, baik itu kegiatan harian ataupun kegiatan mingguan.

Tidak ada penilaian khusus dalam program ini, evaluasi dilakukan dengan mengadakan rapat rutin setiap meinggunya untuk mengevaluasi kegiatan belajar sampai pembiasaan yang dilakukan, guru yang setiap harinya bersama siswa akan melaporkan temuan-temuan yang mereka dapatkan. Pihak sekolah juga memiliki buku pengecekan pelaksanaan program Kurassaki dan setiap bulannya mengumumkan kelas terbersih.

Adanya pelatihan dari pembina program Kurassaki yang diikuti oleh guru-guru agar dapat lebih optimal dalam melaksanakan program Kurassaki, pengoptimalan ini dilakukan dengan mengupayakan semua pihak sekolah agar dapat berpartisipasai dalam pelaksanaan program Kurassaki, terutama guru. Guru menjadi contoh bagi siswa harus berpartisipasi secara maksimal dengan tidak bosan untuk mengingatkan dan menegur siswa dalam pelaksanaan program ini. Selain itu, komunikasi guru dengan orang tua siswa dan pedagang sekitar juga menjadi salah satu bentuk partisipasi guru dalam mensukseskan pelaksanaan program Kurassaki.

10. Adakah kesulitan Di awal pelaksanaan program Kurassaki masih ada saja guru yang ditemukan pada awal yang membeli makanan dengan menggunakan plastik atau pelaksanaan program Kurassaki dari sisi guru? styrofoam, namun saat ini sudah tidak ada kesulitan dari guru untuk berpartisipasi secara maksimal, karena dari kepala sekolahnya yang selalu menegur guru yang kurang berpartisipasi dalam pelaksanaan program, dan sesama guru juga saling mengingatkan.

\begin{tabular}{|l|l|}
\hline $\begin{array}{l}\text { 11. Bagaimana sikap } \\
\text { kepala sekolah } \\
\text { terhadap guru yang } \\
\text { kurang } \\
\text { berpartisipasi dalam } \\
\text { pelaksanaan } \\
\text { program Kurassaki? }\end{array}$ & $\begin{array}{l}\text { Kepala sekolah selalu menegur guru yang kurang berpartisipasi } \\
\text { dalam pelaksanaan program. }\end{array}$ \\
\hline $\begin{array}{l}\text { 12. Apa saja yang } \\
\text { menjadi faktor } \\
\text { pendukung dari } \\
\text { siswa dalam } \\
\text { pelaksanaan }\end{array}$ & $\begin{array}{l}\text { Usia anak sekolah dasar yang sifatnya imitatif (meniru) dan } \\
\text { masih mudah untuk diatur serta diarahkan, memudahkan bagi } \\
\text { pendidik untuk membiasakan siswa mengikuti aturan dan } \\
\text { kegiatan dalam pelaksanaan program Kurassaki sebagaimana } \\
\text { mestinya, seperti tidak membawa sampah ke lingkungan }\end{array}$ \\
\hline
\end{tabular}


Annisa, Suparno, Ujang. Penanaman Karakter Peduli Lingkugan program Kurassaki? ekolah, membawa tempat makan dan tempat minum dari rumah, hal inilah yang menjadi faktor pendukung dari siswa terhadap pelaksanaan program Kurassaki.

13. Adakah hambatan yang ditemukan pada awal Terdapat faktor penghambat di awal pelaksanaan program Kurassaki, yaitu banyak siswa yang tidak membawa tempat pelaksanaan program Kurassaki dari sisi siswa? makan dan minum dari rumah, membawa sampah ke lingkungan sekolah, kurang bertanggung jawab dalam menjaga fasilitas yang disediakan sekolah, dan membuang sampah sembarangan.

14. Bagaimana cara menyikapi siswa yang melakukan pelanggaran?

Pihak sekolah selalu memberikan teguran dan nasehat kepada siswa yang melanggar, serta memberikan sanksi yang mengedukasi agar siswa dapat bertanggung jawab atas pelanggaran yang dilakukannya dan tidak mengulanginya lagi dilain waktu.

15. Sarana dan prasarana apa saja yang tersedia dalam mendukung pelaksanaan program Kurassaki?

Sarana dan prasarana yang disediakan oleh sekolah, antara lain: lingkungan sekolah yang bersih, wastefel cuci tangan, toilet guru dan siswa yang bersih, air bersih, semboyan tentang kebersihan yang dipajang di dinding sekolah, sabun, sendal jepit untuk ke kamar mandi, dan alat kebersihan, tetapi sekolah tidak menyediakan tempat sampah.

16. Apa yang menjadi faktor penghambat dalam pelaksanaan program Kurassaki dari sisi sarana dan prasarana?

Terdapat alat kebersihan yang patah, dan tidak adanya tempat sampah menjadi penghambat pelaksanaan program, karena sekolah tersebut biasa menjadi tempat pelatihan guru atau rapat bersama guru sekolah lain. Karena tidak ada tempat sampah, akhirnya sekolah menyediakan trash bag sebagai pengganti tempat sampah jika ada perkumpulan di sekolah tersebut.

17. Disinikan tidak disediakan tempat sampah, jadi jika ada sampah dibuang kemana?

Siswa diminta membawa plastik dari rumah, terutama bagi siswa yang piket. Jika terdapat sampah, maka dimasukan ke plastik atau tas terlebih dahulu dan dibuang setelah pulang sekolah ke tempat sampah yang mereka temukan.

\section{PEMBAHASAN}

Pelaksanaan penanaman karakter peduli lingkungan melalui program Kurassaki di SD Negeri Sukamulya I

Berdasarkan hasil observasi dan wawancara, pelaksanaan penanamkan karakter peduli lingkungan pada siswa di SDN Sukamulya I meliputi tiga tahap kegiatan pokok, yaitu tahap perencanaan, tahap pelaksanaan, dan tahap evaluasi. Pada tahap perencanaan ini, pihak sekolah mempersiapkan segala sesuatunya terlebih dahulu terkait pelaksanaan program Kurassaki dengan melakukan rapat untuk mendiskusikan hal-hal yang dibutuhkan dan perlu dilakukan guna mensukseskan pelaksanaan program Kurassaki sebelum nantinya diterapkan kepada siswa. Banyak hal yang perlu 
Annisa, Suparno, Ujang. Penanaman Karakter Peduli Lingkugan

dipersiapkan dan direncanakan oleh pihak sekolah sebelum melaksanakan program Kurassaki, seperti mengetahui terlebih dahulu tujuan dan hal yang melatarbelakangi diterapkannya program tersebut, menyediakan sarana dan prasarana yang dibutuhkan, menentukan penanggung jawab pelaksanaan program Kurassaki, menyusun program kegiatan, dan mengkomunikasikan pelaskanaan program ini kepada seluruh warga sekolah termasuk orang tua siswa dan pedagang sekitar Kurassaki. Hamalik (2013) berpendapat bahwa visi, misi, dan tujuan dikembangkannya penerapan pendidikan karakter peduli lingkungan dipaparkan dalam tahap perencanaan. Hal ini dilakukan untuk menentukan cara, penanggung jawab, sasaran, anggaran, evaluasi yang dilakukan, serta sarana dan prasarana yang dibutuhkan.

Pembiasaaan rutin merupakan kegiatan di sekolah yang dilakukan terus menerus setiap hari oleh seluruh warga sekolah, kegiatannya dilakukan secara konsisten (Wiyani, 2013). Pada tahap pelaksanaan program Kurassaki terdapat aturan dan kegiatan yang rutin dilakukan oleh guru dan siswa, kegiatan tersebut dilakukan dengan rutin setiap hari, dan ada juga kegiatan yang rutin dilakukan setiap minggu.

Berdasarkan hasil wawancara yang diperkuat dengan hasil observasi, dapat diketahui bahwa kegiatan harian yang rutin dilakukan di sekolah tersebut yaitu, melakukan piket kelas setiap hari sesuai dengan jadwalnya, mencuci tangan setelah melakukan kegiatan, terutama sebelum dan sesudah makan, serta membawa tempat makan dan minum dari rumah. Siswa yang mendapatkan jadwal piket harus datang ke sekolah lebih awal untuk membersihkan dan merapihkan kelas. Setiap siswa yang bertugas piket di hari tersebut harus membawa plastik, karena sekolah tidak menyediakan tempat sampah, dan selepas pulang sekolah barulah plastik tersbut dibuang ke tempat sampah yang mereka temukan. Siswa juga diwajibkan untuk membawa tempat makan dan minum dari rumah dan menggunakannya pada saat mereka jajan, hal ini bertujuan untuk mengurangi jumlah sampah plastik ataupun styrofoam yang dihasilkan oleh setiap individu siswa dari bekas kemasan jajanan yang dibelinya. Sedangkan kegiatan mingguan yang rutin dilakukan di sekolah tersebut adalah pemeriksaan kuku dan SABSIH (Sabtu bersih), kegiatan sabtu bersih meliputi kerja bakti membersihkan lingkungan sekolah dan sekitarnya, senam bersama, dan makan bersama. Selain itu pihak sekolah suka mengadakan kegiatan fun game yang dilakukan setiap dua sampai tiga minggu sekali dengan tujuan agar siswa tidak jenuh 
Annisa, Suparno, Ujang. Penanaman Karakter Peduli Lingkugan dengan kegiatan belajar di kelas, dan dapat memanfaatkan lingkungan sebagai tempat belajar.

Kegiatan rutin inilah yang dapat membentuk karakter peduli lingkungan siswa, karena kegiatannya dilakukan secara konsisten, sehingga lama-kelamaan siswa akan terbiasa melakukan semua kegiatannya dan dapat mengimplementasikannya dalam kehidupan sehari-hari, baik di lingkungan rumah, sekolah, ataupun lingkungan masyarakat. Karakter tidak muncul dengan sendirinya, melainkan hasil dari proses pembentukan, dan dari proses pembentukan tersebut akan tertanam pada diri seseorang secara bertahap (Ardanita, 2017). Hamzah (2013) juga menjelaskan bahwa karakter peduli lingkungan bukanlah sepenuhnya talenta maupun insting bawaan, tetapi juga hasil dari proses pendidikan dalam arti luas yaitu pendidikan berlangsung seumur hidup selama ada pengaruh dari lingkungan, kepedulian lingkungan hidup merupakan sikap seseorang yang ditunjukkan melalui tindakan atau perilakunya.

Setiap kegiatan atau pembiasaan yang dilakukan siswa selalu didampingi dan diawasi oleh guru. Guru memberikan pendampingan kepada siswa dalam melaksanakan kegiatan program Kurassaki, seperti turut serta dalam kerja bakti, mengingatkan siswa untuk mengikuti setiap kegiatan dan aturan dari pelaksanaan program Kurassaki, serta mengawasi siswa saat melakukan piket kelas. Pernyataan tersebut sesuai dengan pendapat Wiyani (2013) yang mengemukakan proses menciptakan budaya sekolah yang berbasis pendidikan karakter di SD dapat dilakukan dengan pembiasaan keteladanan, yaitu melakukan kegiatan poistif setiap hari agar terbiasa, dengan begitu akan terbentuk sikap dan perilaku peduli terhadap lingkungan dengan sendirinya. Keteladanan merupakan sikap dan perilaku dari tenaga pendidik, siswa, serta seluruh warga sekolah. Pembiasaan keteladanan yang biasa dilakukan di sekolah antara lain: tidak membuang sampah sembarangan, piket kelas, serta melakukan kerja bakti.

Hamalik (2013) menyatakan bahwa evaluasi merupakan tahap untuk mengetahui sejauh mana keberhasilan dari pelaksanaan suatu program sekaligus mengetahui kekurangannya yang perlu diperbaiki. Hasil akhirnya mengarah pada pencapaian susunan indikator dalam tahap perencanaan. Kegiatan evaluasi yang dilakukan oleh pihak sekolah adalah rapat secara berkala yang dilakukan setiap minggunya, hal ini dilakukan dengan membahas segala kegiatan di sekolah yang salah satunya adalah pelaksanaan program Kurassaki, selain itu sekolah juga membuat buku pengecekan 
Annisa, Suparno, Ujang. Penanaman Karakter Peduli Lingkugan

pelaksanaan program yang dipegang oleh penanggung jawab program Kurassaki dan setiap bulannya sekolah akan mengumumkan tiga kelas yang menjadi kelas terbersih. Dari evaluasi ini juga dapat diketahui apa saja yang menjadi faktor pendukung dan penghambat pada saat pelaksanaan, dalam hal ini pelaksanaan implementasi pendidikan karakter peduli lingkungan.

\section{Faktor pendukung dan penghambat pelaksanaan program Kurassaki dalam menanamkan karakter peduli lingkungan pada siswa di SD Negeri Sukamulya I}

Berdasarkan hasil wawancara guru dan kepala sekolah, dalam pelaksanaan program Kurassaki terdapat faktor pendukung dan penghambat dari sisi guru, siswa, serta sarana dan prasarana. Guru menjadi faktor yang paling berpengaruh dalam pelaksanaan setiap program atau pembiasaan di sekolah, berjalan atau tidaknya suatu program tergantung bagaimana guru dalam menerapkan dan menanamkannya pada siswa. Guru-guru SDN Sukamulya I mengikuti pelatihan yang diadakan oleh pembina program Kurassaki dari Bappeda Kabupaten Tangerang untuk mendukung pelaksanaan program dengan bertambahnya pengetahuan dan pengalaman guru setelah mengikuti pelatihan tersebut. Moekijat, 1993 (dalam Sarjilah) yang menyatakan bahwa tujuan pelatihan guru secara umum adalah untuk menambah pengetahuan, keterampilan, serta perbaikan sikap dari guru yang menjadi peserta dalam pelatihan tersebut. Guru juga merupakan sosok yang menjadi teladan bagi anak didiknya, baik buruknya perilaku guru dapat ditiru oleh anak, karena itulah peran guru sangat penting dalam pembentukan karakter anak. Kurniawan (2013) menjelaskan bahwa pendidik merupakan komponen utama yang mendukung pendidikan karakter peduli lingkungan karena pendidik mempunyai kemampuan untuk menanamkan nilai karakter peduli lingkungan pada peserta didik berdasarkan beberapa alasan: 1) Guru mampu menjadi pembimbing atau pengasuh bagi peserta didik, 2) Guru merupakan figur yang ditiru oleh peserta didik, 3) Guru dapat menyayangi peserta didik dengan tulus.

SDN Sukamulya I melaksanakan program Kurassaki dengan tujuan untuk menanamkan karakter peduli lingkungan pada siswa melalui pembiasaan dan aturan di dalamnya, oleh karena itu pasrtisipasi siswa dalam mengikuti pelaksanaan program Kurassaki menajdi faktor pendukung keberhasilan dari pelaksanaan progrm Kurassaki. Usia anak sekolah dasar yang sifatnya imitatif (meniru), memudahkan guru untuk 
Annisa, Suparno, Ujang. Penanaman Karakter Peduli Lingkugan

mengatur dan mengarahkan siswa untuk mengikuti aturan dan kegiatan dalam pelaksanaan program Kurassaki secara optimal. Albert Bandura (dalam Yanto, Murni \& Syaripah, 2017) menjelaskan bahwa apa yang dilihat sehari-hari oleh anak dapat ditiru atau dicontoh olehnya dan berpengaruh terhadap pembentukan perilaku anak tersebut. Sal Savere (dalam Yanto, Murni \& Syaripah, 2017) juga menjelaskan bahwa meniru merupakan salah satu hal penting dalam membimbing anak agar berperilaku baik kepada orang lain, dengan begitu orang-orang yang berada disekitar anak akan menjadi contoh atau model yang akan ditiru olehnya (Nuryanti, 2018 dalam Yanto, Murni \& Syaripah, 2017). Sifat anak yang masih meniru apa yang dilihat olehnya memudahkan guru untuk mengarahkan dan membimbing anak untuk berpartisipasi dalam setiap kegiatan di sekolah, dalam hal ini kegiatan program Kurassaki.

Siswa merupakan individu yang memiliki sifat imitatif (meniru), apa yang dilihatnya pasti ditiru, karena itulah guru dituntut untuk selalu memberikan contoh yang baik agar apa yang ditirunya merupakan hal-hal yang positif, baik dari ucapan maupun perilakunya. Jika siswa dibiasakan untuk mengikuti aturan dan kegiatan dalam pelaksanaan program Kurassaki secara optimal, maka dengan sendirinya akan terbentuk karakter peduli lingkungan pada diri siswa. Ditanamkannya karakter peduli lingkungan sejak dini pada anak agar nantinya mereka dapat menjadi manusia yang bertanggung jawab dan peduli dalam menjaga lingkungan sekitarnya. Sejalan dengan itu, Daryanto \& Darmiatun (2015) yang berpendapat bahwa terjadinya korelasi antara lingkungan dengan manusia, manusia sebagai makhluk yang berakal harus bertanggung jawab untuk mengelola lingkungan. Pendidikan merupakan salah satu wadah atau tempat untuk mempelajari pengelolaan lingkungan hidup, sehingga terdapat istilah karakter peduli lingkungan. Pendidikan tersebut dapat dilaksanakan secara formal maupun nonformal.

Kegiatan dan aturan yang digunakan dalam melaksnakan program Kurassaki memang dibuat untuk membentuk karakter peduli lingkungan siswa, seperti membawa tempat makan dan minum dengan tujuan untuk mengurangi sampah plastik dan styrofoam yang dihasilkan siswa, serta tidak membawa dan membuat sampah di lingkungan sekolah. Pembiasaan tersebut sesuai dengan Kemendiknas tahun (2010) tentang karakter peduli lingkungan adalah sikap dan tindakan untuk mencegah terjadinya kerusakan lingkungan alam sekitar serta berupaya untuk memperbaiki segala 
Annisa, Suparno, Ujang. Penanaman Karakter Peduli Lingkugan

kerusakan alam yang telah terjadi. Karakter peduli lingkungan merupakan karakter yang wajib diimplementasikan di sekolah sejak dini agar setiap individu sadar akan pentingnya kepedulian terhadap lingkungan dan mencegah kerusakan lingkungan (Purwanti, 2017)

Pada dasarnya setiap individu siswa memiliki karakteristik yang berbeda-beda, ada siswa yang mudah untuk diatur, dan ada juga yang sulit diatur. Siswa yang tidak mau mengikuti aturan inilah yang menjadi penghambat dalam pelaksanaan program Kurassaki. Pelanggaran yang biasa dilakukan oleh siswa yaitu lupa membawa tempat makan dan minum dari rumah, masih membawa sampah ke lingkungan sekolah, dan membuang sampah sembarangan. Kebanyakan siswa yang melanggar biasanya dari kelas tinggi, hal ini terjadi karena mereka merasa sudah besar jadi malu dan merasa repot untuk membawa tempat makan dan minum dari rumah. Namun seiring dengan berjalannya waktu siswa mulai terbiasa dengan adanya pembiasaan tersebut, dan pelanggaran-pelanggaran juga mulai berkurang, hal ini terjadi karena pihak sekolah baik guru maupun kepala sekolah selalu mengingatkan siswanya agar mengikuti aturan yang ada, dan tidak pernah bosan untuk menegur serta menasehati siswa yang melanggar.

Sarana dan prasarana merupakan salah satu faktor penting yang mendukung terlaksananya setiap kegiatan termasuk pelaksanan program Kurassaki. SD Negeri Sukamulya I menyediakan alat dan fasilitas yang cukup memadai untuk menunjang terlaksananya program Kurassaki dengan baik, dalam hal ini pihak sekolah juga menggunakan anggaran dengan sebaik mungkin agar segala kebutuhan siswanya dapat terpenuhi. Wiyani (2013) berpendapat bahwa salah satu faktor yang mendukung keberhasilan pelaksanaan pendidikan karakter peduli lingkungan adalah pembiayaan, yaitu anggaran sekolah terkait pelaksanaan pendidikan karakter peduli lingkungan. Pembiayaan diatur dan digunakan sesuai dengan kebutuhan untuk mensukseskan pelaksanaan pendidikan.

Fasilitas yang disediakan oleh sekolah untuk mendukung pelaksanan program Kurassaki antara lain: wastafel atau tempat cuci tangan yang disediakan di depan setiap kelas kecuali di gedung kelas yang baru, terdapat semboyan-semboyan tentang menjaga kebersihan yang dipajang di dinding sekolah, sanisek siswa dan guru yang bersih, sabun, sendal jepit untuk digunakan saat ke kamar mandi, dan juga alat-alat kebersihan, tetapi sekolah tidak menyediakan tempat sampah dikarenakan hal tersebut termasuk 
Annisa, Suparno, Ujang. Penanaman Karakter Peduli Lingkugan peraturan dari dinas. Wiyani (2013) menjelaskan bahwa pengkondisian dilakukan agar terlaksananya pendidikan karakter dengan membangun situasi yang mendukung, seperti tersedianya toilet bersih, halaman yang hijau dengan pepohonan, tempat sampah, serta slogan-slogan atau semboyan tentang kepedulian terhadap lingkungan, kebersihan, dan kesehatan diri yang dipajang di lingkungan sekolah.

Program Kurassaki dilaksanakan dengan tujuan untuk membantu pemerintah dalam mengurangi volume sampah di Kabupaten Tangerang, karena itulah sekolah yang melaksanakan program ini tidak menyediakan tempat sampah baik di kelas maupun di lingkungan sekolah. Namun, menurut pihak sekolah hal ini pernah menjadi masalah di awal pelaksanaan karena SDN Sukamulya I sering dijadikan sebagai tempat rapat yang melibatkan guru ataupun pihak luar sekolah dan membutuhkan konsumsi yang pasti nantinya menghasilkan sampah. Akhirnya pihak sekolah memberikan solusi dengan menyediakan trashbag sebagai pengganti tempat sampah pada saat ada kegiatan rapat bersama guru dari sekolah lain, selain itu pihak sekolah juga meminta setiap siswa untuk membawa plastik dari rumah, terutama untuk siswa yang mendapat jadwal piket, plastik tersebut dijadikan sebagai pengganti tempat sampah, kemudian sampah tersebut dibuang oleh siswa setelah pulang sekolah di tempat sampah yang mereka temui baik di jalan ataupun di rumah.

Sampai saat ini masih terdapat hambatan dari sisi sarana dan prasarana, yaitu adanya alat kebersihan yang hilang dan rusak karena masih kurangnya tanggung jawab siswa dalam menjaga alat-alat kebersihan di sekolah. Alat kebersihan yang patah atau hilang akan dibelikan lagi oleh sekolah, tetapi karena masih sering terulang, akhirnya kepala sekolah membuat aturan jika terdapat alat kebersihan hilang atau rusak, maka kelas tersebut harus menggantinya, hal ini dilakukan agar setiap siswa memiliki rasa tanggung jawab untuk menjaga dan merawat fasilitas yang telah disediakan oleh sekolah

\section{SIMPULAN}

Hasil penelitian dan pembahasan hasil penelitian yang peneliti peroleh saat melakukan penelitian di SD Negeri Sukamulya I, dapat disimpulkan beberapa hal berikut sebagai jawaban atas pokok permasalahan dalam penelitian ini: 


\section{Annisa, Suparno, Ujang. Penanaman Karakter Peduli Lingkugan}

1. Pelaksanaan penanaman karakter peduli lingkungan pada siswa di SDN Sukamulya I melalui program Kurassaki meliputi perencanaan, pelaksanaan, dan evaluasi. Perencanaan dibuat melalui rapat untuk membahas penyusunan program kegiatan, penyediaan sarana prasarana, pembentukan penanggung jawab, dan mensosialisasikannya kepada siswa, orangtua siswa dan pedagang. Pelaksanaannya meliputi kegiatan rutin harian dan mingguan. Kegiatan harian yang rutin dilakukan yaitu piket, membawa plastik, tidak membawa tissue, mencuci tangan, serta membawa tempat makan dan minum. Kegiatan mingguannya meliputi pemeriksaan kuku dan SABSIH (Sabtu bersih), kegiatannya meliputi kerja bakti membersihkan lingkungan sekolah dan sekitarnya, senam, dan makan bersama, serta melakukan kegiatan fun game setiap 2-3 minggu sekali. Tidak ada penilaian khusus dalam evaluasi, sekolah hanya melakukan rapat secara berkala setiap minggunya untuk membahas segala kegiatan di sekolah termasuk pelaksanaan program Kurassaki, melakukan pengecekan pelaksanaan program Kurassaki dan mengumumkan tiga kelas terbersih setiap bulannya.

2. Faktor pendukung dan penghambat dalam pelaksanaan program Kurassaki terdiri dari sisi guru, siswa, serta sarana dan prasarana. Faktor pendukung dari sisi guru yaitu adanya pelatihan dari pembina program Kurassaki dari Bappeda Kabupaten Tangerang yang diikuti oleh guru, berkomunikasi dengan orang tua siswa dan pedagang sekitar sekolah, tidak bosan untuk menasehati, menegur, dan mengingatkan siswa untuk taat terhadap aturan, dari sisi siswa adalah masih mudahnya pada usia anak sekolah dasar untuk diarahkan sehingga siswa dapat berpartisipasi dalam mendukung pelaksanaan kegiatan program Kurassaki, dan dari sisi sarana prasarana yaitu lingkungan sekolah yang bersih, tersedianya air bersih untuk kebutuhan sanitasi, tersedia wastafel cuci tangan dan sabun, tersedia semboyan tentang kebersihan yang dipajang di dinding sekolah, tersedia sendal jepit untuk ke kamar mandi, dan tersedianya alat kebersihan. Hambatan dari sisi siswa yaitu lupa membawa tempat makanan dan minuman, serta kurangnya tanggung jawab dalam pemeliharaan alat kebersihan, hambatan dari sisi sarana dan prasarana adalah terdapat alat kebersihan yang rusak dan hilang. 
Annisa, Suparno, Ujang. Penanaman Karakter Peduli Lingkugan

\section{SARAN}

Berdasarkan hasil penelitian ini, maka peneliti ingin menyampaikan beberapa saran yang diharpkan dapat bermanfaat bagi pembaca: (1) Bagi Kepala Sekolah diharapkan dapat menjadi pemimpin yang tegas dan konsisten dalam menjalankan setiap program-program disekolah, (2) Bagi Guru, hendaknya dapat lebih membantu dan berpartisipasi aktif dalam mensukseskan setiap program, kegiatan ataupun pembiasaan yang dilakukan untuk membentuk karakteristik siswa di sekolah, (3) Bagi peneliti lain, semoga dapat melakukan penelitian lebih baik lagi, sehingga hasil yang diperoleh pun lebih baik, maka disarankan untuk membangun komunikasi yang baik dengan pihak sekolah supaya lebih mudah dalam menyesuaikan jadwal dan waktu penelitiannya.

\section{UCAPAN TERIMA KASIH}

Tanpa mengurangi rasa syukur kepada Allah SWT, saya mengucapkan terima kasih kepada semua pihak yang telah mendukung penyelesaian penelitian ini, terutama:

1. Kedua orangtua, kakak, dan juga semua keluarga yang selalu mendoakan, menyemangati, dan mendukung dalam penyelesaian penelitian ini.

2. Bapak Dr. Suparno, M.Pd dan Bapak Dr. Ujang Jamaludin, M.Si., M.Pd selaku dosen pembimbing yang telah memberikan do'a, bimbingan, serta dukungan dalam menyelesaikan penelitian ini.

3. Teman-teman dan semua pihak yang telah bekerja sama dan membantu kelancaran penelitian ini.

\section{DAFTAR RUJUKAN}

Admin Kabupaten. 2016. Bappeda Kabupaten Tangerang Luncurkan Program Kurasaki untuk Atasi Sampah. Diakses melalui http://bappedatangerangkab.com/?p=348, 17 Oktober 2016.

Ardanita, Bela Amanda. 2017. Membentuk Karakter Peduli Lingkungan melalui Komunitas Pelajar Peduli Lingkungan Hidup (KPPLH). Seminar Nasional Teknologi Pembelajaran dan Pendidikan Dasar, Vol. 7 No. 4, Mei 2017, hal. 969-974.

CNN Indonesia. 2018. Kesadaran Mayarakat Indonesia akan Kebersihan Masih Rendah. Diakses melalui https://www.cnnindonesia.com/gayahidup/20180423183600-255-292946/kesadaran-masyarakat-indonesia-akankebersihan-masih-rendah, 19 November 2019.

Daryanto dan Darmiatun, Suryatri. 2015. Implementasi Pendidikan Karakter Di Sekolah. Yogyakarta: Gava Media. 
Annisa, Suparno, Ujang. Penanaman Karakter Peduli Lingkugan

Hamalik, Oemar. 2013. Proses Belajar Mengajar. Jakarta : PT. Bumi aksara.

Hamzah, Syukri. 2013. Pendidikan Lingkungan. Bandung: Rafika Aditama.

Kemendiknas. 2010. Pengembangan Pendidikan Budaya dan Karakter Bangsa. Jakarta: Balitbang.

Kurniawan, Syamsul. 2013. Pendidikan Karakter: Konsepsi \& Implementasinya secara terpadu di lingkungankeluarga, sekolah, perguruan perguruan tinggi \& masyarakat. Yogyakarta: Ar-Ruzz Media.

Mulyadi, Mohammad. 2011. Penelitian Kuantitatif dan Kualitatif Serta Pemikiran Dasar Menggabungkannya. Jurnal Studi Komunikasi dan Media, Vol. 15 No. 1, Juni 2011, hal. 127-138.

Ninsih, Tri Rostia, Winarni, Endang Widi, \& Karjiyati, Victoria. 2018. Pendidikan Karakter Peduli Lingkungan melalui Program "Mahira Bebas Sampah" di SD Alam Mahira Kota Bengkulu. Jurnal Pendidikan Guru Sekolah Dasar, 1 (1) : 73-82.

Purwanti, Dwi. 2017. Pendidikan Karakter Peduli Lingkungan dan Implementasinya. Dwija Cendekia : Jurnal Riset Pedagogik, Vol. 1 No. 1, Desember 2017, hal. 14-20.

Purwanto, Setyoadi. 2016. Pendidikan Karakter melalui Seni. Yogyakarta: Pustaka Pelajar.

Rahmat, Pupu Saeful. 2009. Penelitian Kualitatif. EQUILIBRIUM, Vol. 5 No. 9, Juni 2009, hal. 1-8.

Sarjilah. Makna Pengembangan Manusia pada Pelatihan Guru. Tersedia (Online) http://file.upi.edu/Direktori/FIP/JUR._PEND._LUAR_SEKOLAH/1957092519 84031-ADE_SADIKIN_AKHYADI/KaryaTulis-MaknaPMTakeHome.pdf ， diunduh pada tanggal 23 April 2020.

Setio, Hadi. 2017. Kebersihan Lingkungan Sekolah. Diakses melalui https://fasilitasi.bpmtv.kemdikbud.go.id/kebersihan-lingkungan-sekolah-2/, 19 November 2019.

Wiyani, Novan Ardy. 2013. Konsep, Praktik dan Strategi Membumikan Pendidikan Karakter di SD. Yogyakarta: Ar-ruzz Media.

Yanto, Murni dan Syaripah. 2017. Penerapan Teori Sosial dalam Menumbuhkan Akhlak Anak Kelas I Madrasah Ibtidaiyah Negeri 1 Rejang Lebong. Jurnal Pendidikan dan Pembelajaran Dasar, Vol. 4 No. 2, Oktober 2017, hal. 66-67. 